SAbina Giergiel

Uniwersytet Jagielloński

\title{
„Rzeka to nie ziemia, przyjmie wszystko". Uwag kilka o przyrodniczych uwarunkowaniach Zagłady w Serbii
}

W artykule otwierającym poświęcony środowiskowej historii Zagłady numer „Tekstów Drugich” Przemysław Czapliński stwierdza, że do rozważań o warunkach, które umożliwiły Holokaust, należy dodać kolejny parametr, a mianowicie lokalizację. Przestrzeń może być „naturalnym” wrogiem lub sprzymierzeńcem nazistów, świadkiem lub ofiarą (Czapliński 2017: 11). Dla niniejszych rozważań te wstępne konkluzje są kluczowe. Zamierzam bowiem wskazać na relację, jaka zachodziła pomiędzy wodą (a dokładnie tokami rzecznymi) a Holokaustem na terytorium dzisiejszej Serbii. Pragnę zatem poświęcić swoją uwagę pewnym środowiskowym uwarunkowaniom Zagłady, akcentując zwłaszcza wpływ okoliczności hydrologicznych na lokalizowanie obozów. Pośrednio odniosę się ponadto do warunków pogodowych jako czynnika, który wpływał zarówno na losy więźniów, jak i na charakter działań eksterminacyjnych, jakie miały miejsce w styczniu 1942 roku w serbskiej Wojwodinie. W rozważaniach podążam za literackimi obrazami przemocy, które zostały utrwalone na kartach serbskich fikcjonalnych utworów podejmujących tematykę związaną z Holokaustem. Pragnę podkreślić, że moje uwagi mają charakter wstępny. Zwracając uwagę na to, co wciąż sytuuje się poza obrębem zainteresowań badaczy zajmujących się Zagładą na terenie Serbii, otwieram zatem pole do bardziej szczegółowych analiz. 
Kwestia środowiskowego uwarunkowania działań eksterminacyjnych pojawia się w polu rozważań nazistów (od kwietnia 1941 roku okupujących centralną część Serbii) praktycznie od momentu ich wejścia do kraju. Już w kwietniu, zapewne w związku z nasilającymi się akcjami dywersyjnymi partyzantów, w kręgu członków niemieckiej administracji rozpoczęto bowiem rozmowy na temat lokalizacji miejsc internowania. Równocześnie zainicjowano poszukiwania odpowiedniego terenu, na którym miał zostać zorganizowany centralny (w skali kraju) obóz koncentracyjny.

Jesienią rozpoczynają się wstępne prace budowlane na terenie położonym około $70 \mathrm{~km}$ od Belgradu, nieopodal Sremskiej Mitrovicy. Pod budowę obozu przeznaczono tam przestrzeń o długości $12 \mathrm{~km}$ i szerokości $3,5 \mathrm{~km}$. Niebagatelnym atutem tego miejsca było jego geograficzne usytuowanie, a mianowicie fakt, że teren wyznaczały naturalne granice (Manošek 2007: 74). Z trzech stron otaczała go rzeka Sava (granica Serbii i Chorwacji), z czwartej zaś bagniste okolice rzeki Zasavicy. Paradoksalnie jednak to, co zdecydowało o wyborze tego miejsca, a mianowicie bliskość rzeki, stanowiącej w opinii nazistów nie tylko wygodny tok komunikacyjny dla zaopatrzenia przyszłego obozu, ale również zapewniającej niedostępność, ostatecznie doprowadziło do zarzucenia planów budowy. Uwarunkowania hydrologiczne uniemożliwiły bowiem prace naziemne: bezpośrednia bliskość rzeki powodowała znaczne zawilgocenie terenu, a wręcz potęgowała jego bagnistość. Było to szczególnie uciążliwe podczas deszczowej jesieni (a taką była jesień 1941 roku). Trwające nieprzerwanie przez cztery tygodnie ulewy spowodowały podniesienie się wód gruntowych, co zablokowało wjazd ciężarówek na teren planowanego obozu (Vojinović 2015: 396). Podmokłość terenu wokół Zasavicy sprawiła, że zarzucono plany zorganizowania tam obozu, a następnie podjęto decyzję o wykorzystaniu w tym celu już istniejącej infrastruktury. Wybrano teren, na którym kilka lat przed wybuchem wojny w ramach planu rozbudowy i modernizacji Belgradu wzniesiono hale ekspozycyjne dla targów i wystaw (Bogusławska 2016: 470). To tam właśnie powstał obóz Sajmište będący ważnym symbolem Zagłady w Serbii, ale i istotnym elementem europejskiej pamięci o Holokauście (Browning 2012: 99-100). Pod względem fizycznym był to obszar wchodzący w obręb dzisiejszego Belgradu, o wielkości 20 ha, położony na lewym brzegu rzeki Savy pomiędzy Mostem Branka i tzw. Starym Mostem. Przed wojną i w jej trakcie obszar znajdował się na peryferiach serbskiej stolicy. Co więcej, planowany obóz był tak usytuowany, że sprawiał wrażenie niezbyt ściśle połączonej z Belgradem satelity. Od miasta $\mathrm{z}$ jednej strony odgradzała go rzeka, a z drugiej bagna oddzielające serbską stolicę od Zemunu (Bajford 2011: 13). 
Jeden z serbskich historyków wybór tej właśnie lokalizacji na centralne miejsce internowania uznaje za zaskakujący:

Na terytorium Serbii na lokację obozów wybierano najczęściej koszary lub inne budynki wojskowe, znajdujące się na peryferiach dużych miast. Zwykle były to obiekty nierzucające się w oczy, relatywnie odizolowane. Wybór przestrzeni belgradzkich targów, znajdujących się tuż przed oczami Belgradu, można tłumaczyć pośpiechem [nazistów - S.G.] (Koljanin 1992: 49)'.

Badacz, wyrażając zdziwienie wyborem miejsca, wyraźnie akcentuje jego położenie: „przed oczami mieszkańców Belgradu”. I właśnie ten fragment jego wypowiedzi wydaje mi się kluczowy. Chociaż od ścisłego centrum oddzielała bowiem Sajmište jedynie około kilometrowa odległość (Bajford 2011: 27), to jednak obóz znajdował się na ówczesnych peryferiach: w dzisiejszej dzielnicy Zemun, będącej niegdyś aglomeracją administracyjnie oddzieloną od położonego na przeciwległym brzegu Savy Belgradu.

\section{Rzeka jako grób}

W problematyce holokaustowej rzeka jest przykładem aktora $\mathrm{z}$ drugiego, a nawet z trzeciego planu, który jeszcze niedawno był praktycznie pomijany w refleksji nad aktorami planu pierwszego, czyli ludźmi (Czapliński 2017: 13). W literackich reprezentacjach Zagłady rzeka bywa postrzegana jako masowy grób. Podobnie jak osuwiska, doły, szczeliny jest naturalnym elementem otoczenia, w którym można porzucić (lub do którego można wrzucić) ciała. Ze względu na specyfikę swego istnienia, którego konstytutywnym elementem jest niemożliwy do zatrzymania ruch, zdaje się ponadto właściwszym miejscem do ukrycia zwłok niż doły grzebalne. A zatem bliskość rzeki niejednokrotnie umożliwiała sprawcom zbrodni efektywne pozbycie się ciał, a zarazem śladów zbrodni. Aby zilustrować te spostrzeżenia, przywołajmy fragment $\mathrm{z}$ książki Hideg napok (Zimne dni) węgierskiego pisarza Tibora Cseresa:

Cała operacja [topienia ciał w Dunaju - S.G.] jest możliwa z tego względu, że [...] nurt swobodnie poniesie w dół rzeki każde powierzone

1 Dla uściślenia dodajmy, że w październiku wyznaczono granicę pomiędzy okupowaną przez Niemców centralną Serbią a terytorium NDH (Niezależne Państwo Chorwackie). W wyniku tych decyzji obóz Sajmište znalazł się na terytorium NDH. Tłumaczenia tekstów, o ile nie zaznaczono inaczej, pochodzą od autorki artykułu. 
mu zwłoki. [...] W temperaturze około zera zwłoki nie poddają się tak łatwo procesowi gnicia. Doczekają wiosny. Ale gdzie już wtedy będą! Co najmniej w morzu, jeśli oczywiście nie zaczepią się gdzieś po drodze o jakieś podwodne korzenie (Cseres 1980: 46).

W literaturze serbskiej obraz rzeki jako grobu pojawia się w kontekście historycznych wydarzeń, jakie zimą 1942 roku miały miejsce w przyłączonej do Węgier części Wojwodiny, tj. na terenie południowej Baczki. Wówczas w Nowym Sadzie przez kolejne trzy dni trwały masowe akcje represyjne, których (według oficjalnej wersji wydarzeń) celem było „oczyszczanie obszaru z oddziałów partyzanckich oraz «niepożądanego» i «nielojalnego» elementu" (Bukwalt 2018: 2). W istocie jednak były to akcje odwetowe za starcia pomiędzy węgierskimi siłami i jednym z serbskich oddziałów partyzanckich (Rotbart 2013: 283-284). Kulminacją operacji, mającej na celu „oczyszczenie” Baczki z tzw. bandytów, była masakra ludności cywilnej, jaka w Nowym Sadzie trwała od 21 do 23 stycznia 1942 roku. W jej wyniku zginęło prawdopodobnie około 4000 mieszkańców, wśród których najliczniejszą grupę stanowili Żydzi i Serbowie. Akcja została dokładnie przygotowana, wstępem do niej było otoczenie miasta przez siły porządkowe. Sama operacja miała zaś niezwykle brutalny charakter. Przedstawiciele węgierskich służb porządkowych od rana do późnych godzin wieczornych przetrząsali ulice w poszukiwaniu domniemanych partyzantów. Mieszkańców Nowego Sadu mordowano zarówno w domach, jak i na ulicach, na których pozostawiano zwłoki ofiar. Najtragiczniejszy los spotkał jednak tych, których przetransportowano na miejską plażę, tam bowiem topiono ich w Dunaju².

Tym właśnie wydarzeniom poświęcił swoją książkę Erih Koš, który w powieści Novosadski pokolj (Nowosadzka masakra)3 z 1961 roku opisuje kilka styczniowych dni poprzedzających akcję oraz sam jej przebieg. W tym miejscu

2 Podobne akcje miały miejsce w wielu miejscowościach południowej Baczki. Przykładowo we wsi Čurug zamordowano około 900 osób, których ciała następnie wrzucono do Cisy (Mesta stradanja..., dostęp 2021). Warto dodać, że na promenadzie nad Dunajem W 1971 roku stanął pomnik upamiętniający te wydarzenia (w historiografii określane mianem pogromu nowosadzkiego, serb. novosadska racija). Pomnik zaprojektował Jovan Soldatović. Zdjęcia pomnika dostępne na stronie internetowej, zob. Spomenik Žrtvama Racije, dostęp 2021.

3 Wydarzenia te stają się tłem dla przedstawienia sylwetki głównego bohatera w jednej z powieści Aleksandara Tišmy, Knjiga o Blamu (Księga Blama). Naturalistyczny opis egzekucji znajdziemy w utworze Danila Kiša Psalam 44 (Psalm 44), echo wydarzeń obecne jest również w jego utworze pt. Peščanik (Klepsydra). Pomijam je tutaj całkowicie, nie odnajduję w nich bowiem obrazów wskazujących na sprawczość natury. 
pragnę wskazać na rozsiane po tekście drobne uwagi, w których ujawnia się perspektywa wiążąca działania ludzkich aktorów z podmiotami, które do tej pory w refleksji holokaustowej były zwykle pomijane (są to warunki pogodowe, a przede wszystkim rzeka).

Jak czytamy zarówno w utworach fikcjonalnych, jak i w tekstach historiograficznych, problematyzujących zagadnienie Zagłady w Serbii, zima 1942 roku była szczególnie mroźna. Należy podkreślić, że właśnie zimowe miesiące były decydujące dla losów serbskich Żydów. Wówczas zaczyna bowiem funkcjonować obóz Sajmište, do którego od początku grudnia przewożono pozostałych przy życiu przedstawicieli narodu żydowskiego. Dojmujący mróz daje się we znaki zarówno podczas transportu do miejsca przeznaczenia, jak i w czasie internowania. Pogoda, a więc czynnik nie-ludzki, okazuje się zatem mieć niebagatelny wpływ na egzystencję więźniów.

W tym miejscu interesuje mnie jednak szczególnie mróz (dochodzący w styczniu 1942 roku do minus 30 stopni), a dokładnie serbskie rzeki, które zimą 1942 roku były skute lodem. Dunaj przepływający przez Nowy Sad pokryty był grubą warstwą lodu, ale - jak dowiadujemy się z powieści Koša - środkowa część koryta pozostała niezamarznięta. To właśnie ta czarna czeluść staje się pułapką dla tych, którzy nocą, w obawie przed pogromem, próbują przedostać się z otoczonego przez żołnierzy i żandarmów miasta na drugi brzeg (Koš 1961: 117). Ponieważ dojmujący mróz uniemożliwia kopanie dołów grzebalnych, funkcję grobu przejmuje rzeka. Inaczej niż ziemia, stawiająca bierny opór „rzeka może wszystko przyjąć” (Koš 1961: 136). Jednak podczas nowosadzkiego pogromu w Dunaju nie tylko topiono ciała już zamordowanych. Zapewne w celu usprawnienia prowadzonej „akcji oczyszczania miasta z bandytów” strzałokrzyżowcy przez dwa kolejne dni rankiem wyrąbywali w lodzie przerębel, nad którą dokonywali egzekucji. Na ironię zakrawa fakt, że poprzedzały ją etapy podobne do przygotowań do letniej kąpieli. Przyszłe ofiary najpierw transportowano do bramy prowadzącej na plażę. Ustawieni w szeregu ludzie następnie trafiali do pomieszczenia, które latem służyło jako przebieralnia. Tam się rozbierano, a po wyjściu ustawiano w kolumny, by w szeregu czekać na swoją kolej wejścia na lód. Na zamarzniętym Dunaju zaś „ustawili się oficerowie, którzy wraz z dziesięciorgiem żandarmów utworzyli krąg wokół rankiem wyrąbanej przerębli, w której czarna woda wrzała jak w kotle” (Koš 1961: 134, wyróż. - S.G.).

O rzece w trakcie nowosadzkiego pogromu wspomina także w utworze Aveti iz jednog malog grada (Upiory z pewnego miasteczka) Ivan Ivanji. Jedna z bohaterek powieści zostaje mianowicie wraz z dziećmi zapędzona nad Dunaj. Stojąc w szeregu i czekając na śmierć, przypomina sobie swe letnie kąpiele w rzece. Teraz jednak „to nie był ten sam Dunaj, taki piękny i jasny. Dziś był brzydki 
i mętny" (Ivanji 2009: 152, wyróż. - S.G.). W tekstach, które problematyzują wydarzenia ze stycznia 1942 roku, podkreślony zostaje groźny, a wręcz złowrogi charakter Dunaju. Obraz ten stoi w jawnej opozycji wobec wspominanego niejednokrotnie na kartach tych samych utworów Dunaju sprzed kilku miesięcy. Wówczas była to rzeka, która w czasie upalnych letnich dni dawała wytchnienie mieszkańcom miasta. Zimą jednak sinoczarna, rwąca toń Dunaju pochłania ciała. Rzeka staje się mroczną, nieposkromioną siłą, będącą mimowolnym sprzymierzeńcem funkcjonariuszy.

\section{Rzeka jako mur}

Kinga Piotrowiak-Junkiert, analizując jedno z opowiadań węgierskiego pisarza Mihálya Kornisa (Piotrowiak-Junkiert 2015: 109-123), wskazuje na inną symbolikę rzeki. Pisze mianowicie o Dunaju jako odpowiedniku (fizycznie nieistniejącego) muru: „Odwieczny nurt Dunaju stał się miejscem straceń, zastąpił ścianę muru, który nie otoczył getta" (Piotrkowiak-Junkiert 2015: 112). Właśnie ta przywołana przez Piotrowiak-Junkiert funkcja rzeki jest równie nośna w przypadku interesującej mnie w tej partii tekstu Savy, oddzielającej centrum Belgradu od terenów międzywojennych targów, na których usytuowany został obóz Sajmište. Sava, odgraniczająca od siebie dwa światy, jest naturalnym znakiem odseparowania ${ }^{4}$. Internowani w obozie Sajmište są jakby podwójnie wykluczeni: za sprawą muru, ale i rzeki, która broni do nich dostępu. Symptomatyczny jest fakt, że Żydzi mogą przekroczyć rzekę jedynie w trzech przypadkach: ciężko chorzy, martwi (przenoszeni przez kobiety) lub jako pasażerowie mobilnej komory gazowej (a więc w swej drodze ku śmierci). Tylko w tych sytuacjach Żydzi ponownie wchodzą w przestrzeń wspólnoty5. Jednak przedstawiciele obu społeczności się nie spotykają. Paradoksalność położenia internowanych (tak blisko, a jednocześnie tak daleko) zauważa Hilda Deitch, dziewiętnastoletnia więźniarka i ofiara Sajmišta, która w jednym z zachowanych listów obozowych pisze:

Jesteśmy blisko świata, a jednak tak oddaleni od wszystkich. Z nikim nie mamy kontaktu. Życie ludzi na zewnątrz (za murami) toczy się bez

4 Gordana Todorić ostatnią scenę powieści Koša, w której widzimy, jak na drugą stronę rzeki zostaje przetransportowany jeden z partyzantów, odczytuje w kluczu biblijnym (Todorić, dostęp 2021). Dunaj, będący granicą między Nowym Sadem, w którym odbywa się rzeź, a spokojnym Petrovaradinem również w tym tekście pełni rolę neutralnego muru.

5 O liminalnym charakterze Savy zob. Giergiel 2019: 559-563. 
zmian, jakby pół kilometra dalej nie było rzeźni, w której życie traci sześć tysięcy niewinnych ${ }^{6}$.

\section{Rzeka jako scena ${ }^{7}$}

Zarówno w tekstach historiograficznych, jak i literackich dotyczących Sajmišta pojawia się obraz skutej lodem Savy, przez którą więźniarki przenoszą owinięte w białe prześcieradła zwłoki. Transport ciężko chorych i martwych odbywał się bowiem przez rzekę z terenu obozu (Zemun) do centrum (Belgrad). Na drugim brzegu na kobiety, którym podczas przeprawy przez rzekę towarzyszyli niemieccy funkcjonariusze, czekali przedstawiciele personelu żydowskiego szpitala, którzy ciężko chorych umieszczali w ciężarówce i przewozili do ambulatorium. Zmarli trafiali zaś na cmentarz żydowski (Pisma Hilde Dajč, dostęp 2021). W serbskich tekstach literackich eksponowany jest motyw patrzenia na to/obserwacji z drugiego (belgradzkiego) brzegu tego, co dzieje się na lodzie. Można wręcz odnieść wrażenie, że przed oczami mieszkańców serbskiej stolicy odgrywany jest makabryczny spektakl ${ }^{8}$. W takim ujęciu skuta lodem Sava staje się sceną, a miasto widownią. Takiemu widzeniu relacji pomiędzy obiema przestrzeniami sprzyja geograficzne położenie serbskiej stolicy, której stara część rozpościera się na wzgórzach ${ }^{9}$ Nad miastem góruje zaś twierdza Kalemegdan, będąca do dziś popularnym miejscem spacerów mieszkańców stolicy.

W kontekście dwudzielności przestrzeni i pośrednio wynikającego z niej niezaangażowania warto przywołać fragment wydanej w 2005 roku powieści Zorana Penevskiego Manje važni zločini (Zbrodnie mniej ważne). Mowa jest tam o minutowym filmie odnalezionym przez jednego z pracowników Jugosłowiańskiej Kinoteki. Widać na nim ledwie zarysy kobiet, które ostrożnie suną po lodzie z ciałami martwych, by po przejściu na drugą stronę Savy przekazać

6 Cztery listy Hildy Deitch przeszmuglowane z Sajmišta są unikalnym obozowym świadectwem. W dwóch wersjach językowych (serbskiej i angielskiej) dostępne są na stronie internetowej, zob. Pisma Hilde Dajč, dostęp 2021.

7 Dla tej części tekstu szczególnie inspirujące były dla mnie tezy zawarte w artykule Romy Sendyki Od obserwatorów do gapiów. Kategoria bystanders i analiza wizualna. Zob. Sendyka 2018.

8 Metaforyka teatralna jest wyraźnie obecna w polskiej refleksji holokaustowej. Zob. Niziołek 2013 czy teksty zebrane w tomie Dauksza, Koprowska, red. 2019.

9 Wrażenie to jest szczególnie dojmujące podczas wjazdu do miasta od strony Zemunu (de facto przejeżdża się wówczas obok terenu, na którym usytuowany był obóz) przez tzw. Most Branka (dziś łączący stary Belgrad z Nowym Belgradem) czy most kolejowy. Stare miasto usytuowane jest bowiem na wzgórzach, aby do niego dotrzeć (np. z dworca autobusowego) należy pokonać różnicę wzniesień. 
je przedstawicielom gminy żydowskiej. Szczególnie ważna jest konstatacja, która dotyczy nie tyle rejestrowanych na filmie wydarzeń, ile formalnych aspektów nagrania. Czytamy mianowicie, że obraz ,jest krzywy, film kręcono z wysokości, prawdopodobnie z jakiegoś okna, bo obraz drży. Jakby wykonano go ukradkiem” (Penevski 2005: 133). Usytuowanie „operatora” ponad filmowaną sceną potęguje wrażenie oddzielenia dwóch przestrzeni i wyobcowania tych, którzy są filmowani. Widok $\mathrm{z}$ wysoka ponadto ma powiązania militarne i przemocowe (Sendyka 2019: 96). Nasuwają się tu skojarzenia z polowaniem i amboną myśliwską, ale również z górującą nad terenem więzień i obozów wieżą.

Jeżeli powrócimy do metaforyki teatralnej, to skuta lodem Sava staje się sceną, punkt obserwacyjny zaś - znajdujący się na przeciwległym wobec obozu brzegu - balkonem. Ogląd umożliwia przybliżenie, jakie w teatrze zapewnia lornetka (jej funkcję w tekście Penevskiego przejmuje kamera). Fizyczne oddalenie „widowni” od wydarzeń (zarówno w teatrze, jak i w opisywanym przypadku) gwarantuje poczucie bycia poza tym, co się dzieje, zapewniając tym samym rodzaj usprawiedliwienia dla braku zaangażowania. Mimowolnie nasuwające się skojarzenie teatralne jest niejako podważane przez następujące zdanie, z którego dowiadujemy się, że obraz drży. Film został zapewne nakręcony nie dla zabawy, a wręcz przeciwnie - aby stać się dowodem zbrodni. Obraz prawdopodobnie porusza się dlatego, że obserwator/świadek nie mógł przyjąć wygodnej, stabilnej pozycji (np. oprzeć się o parapet okienny), filmował bowiem z ukrycia coś, co nie powinno zostać zarejestrowane. Możliwe, że się bał i właśnie ten strach ujawnia się w drżeniu ręki.

Przechodząc od planu ogólnego do zbliżenia, widzimy, co dokładnie rejestruje kamera. Otóż na filmie utrwalone zostały:

[...] szare postacie jakichś kobiet, które ostrożnie stąpają po lodzie, ciągnąc ciała. Prawie niezauważalnie, z prawej strony ktoś od nich przejmuje, bez wątpienia, zwłoki. Wokół biel. Śnieg. Jedna z kobiet upada, powierzchnia pęka, wtedy ona się zapada. Czyli tam jest lód. Pozostałe kobiety boją się jej pomóc. Ona znika (Penevski 2005: 133).

Podobnie jak Dunaj dla budapesztańskich czy nowosadzkich Żydów, pochłaniająca kobietę Sava staje się grobem.

\section{Rzeka jako aktant}

Koš swoją powieść publikuje w 1961 roku, utwór Cseresa Zimne dni, o którym wspomniano w początkowej części niniejszego tekstu, został wydany na 
Węgrzech w 1964 roku. Początki historii środowiskowej Jacek Małczyński umiejscawia w latach sześćdziesiątych XX wieku (Małczyński 2018: 21). Wspomniani autorzy nie mogli zatem świadomie nawiązywać do refleksji, która ustanawia relację pomiędzy działaniem ludzkim i działaniem przyrody. A jednak w opowieściach o nowosadzkiej masakrze pojawiają się fragmenty, które można odczytywać w kontekście nowych (zorientowanych środowiskowo) nurtów w badaniach holokaustowych.

Nie należy oczywiście zapominać, że antropomorfizowanie elementów przyrody jest konwencjonalnym zabiegiem literackim. Ponowna, zorientowana środowiskowo lektura pozwala jednak dostrzec to, co do tej pory umykało badaczom. U Cseresa przykładowo znajdujemy obraz, w którym funkcjonariusze podchodzą do przerębli, spoglądają w dół i zauważają, że „woda pluska i gada swoim językiem" (Cseres 1980: 91). Autor udziela zatem głosu bytowi do tej pory uznawanemu za niemy. Oddaje rzece głos literalnie (szum, szemranie rzeki porównane do mowy), ale i metaforycznie. W tym drugim znaczeniu udzielenie głosu rozumieć można - jak mi się wydaje - również jako autorską zgodę na wyrażenia sprzeciwu przez byt przyrodniczy. W kolejnym fragmencie autor wskazuje bowiem na problemy strzałokrzyżowców z zamarzającą rzeką. Woda mianowicie, nasyciwszy się zwłokami, zaczyna stawiać opór tym, którzy zadają gwałt zarówno ofiarom, jak i jej, przemocą wtłaczając ciała do otworu $\mathrm{w}$ lodzie ${ }^{10}$. Jeden $\mathrm{z}$ uczestniczących $\mathrm{w}$ akcji topienia „podejrzanych” $\mathrm{w}$ retrospektywnym fragmencie zauważa:

Drąg był nam niezwykle potrzebny, bo [...] woda zamiast jak to w taki mróz opadać, jeszcze przybierała. Jakżeśmy tylko przebijali przerębel, woda podchodziła do góry i wylewała się na lód. $Z$ tego też względu w połowie przedpołudnia na darmo już Dirner i sierżant wrzucali do przerębla szpiegów, partyzantów i czetników. Wrzucali ich głową do wody, ale po krótkim czasie woda wypychała ich tyłkami do góry (Cseres 1980: 123).

Jeszcze wyraźniej sprawczość rzeki zostaje wyartykułowana w chorwackiej powieści Nebojšy Lujanovicia Oblak boje kože (Chmura w kolorze skóry), problematyzującej zagadnienie Porajmosu ${ }^{11}$. Autor przywołuje w nim dwa najważniejsze dla zagłady Romów toposy, a mianowicie Jasenovac i Auschwitz.

10 Jedną z osób, która w ten sposób ocalała z masakry, był ojciec Danila Kiša. Pisarz w tym kontekście mówi o cudzie (Kiš 1999: 142).

11 Więcej na temat powieści: Giergiel, Taczyńska 2019: 317-336. 
W jednej ze scen powieści czytamy o „buncie” zbiorników wodnych, które nie chcą przyjmować kolejnych ton ludzkiego popiołu, tym samym z sojuszników nazistów stając się ich przeciwnikami. Autor w tym kontekście wspomina o Wiśle, ale prawdopodobnie chodzi mu o Sołę - dopływ Wisły, do której przez pewien czas wrzucano prochy ofiar. Jak zauważa Anita Jarzyna, w wyniku tych działań ten naturalny ciek rzeczny stał się szczególnym nośnikiem pamięci - masowym grobem (Jarzyna 2019: 258). Pierwotnie u Lujanovicia Wisła jest bierna: „oto kolejny sojusznik, którego o nic nie pytano i który nie miał wyboru" (Lujanović 2015: 204). Ostatecznie jednak to rzeka, łagodnie unosząc ciało bohatera podczas jego ucieczki z obozu, pomaga mu przeżyć, by mógł zaświadczyć o popełnionych zbrodniach.

W niniejszym tekście próbowałam przede wszystkim wykazać, że w Serbii, podobnie jak w innych miejscach, „Zagłada [...] nie wydarzyła się w środowiskowej próżni” (Małczyński 2018: 211). Zarysowane tutaj konteksty są jedynie wstępem, przyczynkiem do bardziej szczegółowych badań nad obecnym w tekstach literackich obrazowaniem relacji przyrody i człowieka w trakcie eksterminacji. W swoich rozważaniach poszłam tropem wyznaczonym przez Małczyńskiego we wstępie do jego książki Krajobrazy Zagłady. Wskazałam mianowicie na znaczenie warunków naturalnych dla przebiegu Zagłady. Szczególne miejsce poświęciłam rzece, która w literaturze serbskiej (i chorwackiej - o czym ledwie wspomniałam) staje się ważnym toposem holokaustowym, aktualizującym zwłaszcza symbolikę toku wodnego jako grobu. W kontekście losów Żydów internowanych w obozie Sajmište szczególnego znaczenia nabiera rozumienie rzeki jako muru i zasłony oddzielającej cierpiących Żydów od mieszkańców serbskiej stolicy. Owo odseparowanie, którego widomym znakiem była naturalna granica, a mianowicie Sava, uniemożliwiło zaistnienie interakcji podczas tych rzadkich momentów, w których internowani przekraczali granicę pomiędzy światem i (nie)światem. I w końcu, pozostając w kręgu refleksji poświęconej rzece, wskazuję na wątki kwestionujące rozumienie rzeki jako biernego tła Zagłady. Odwołuję się do powieści Lujanovicia i obecnego w niej intrygującego obrazu wody, bytu antroponimizowanego i sprawczego. Ową sprawczość - jak mi się wydaje - nieśmiało artykułują już Cseres i Koš, jednak dopiero Lujanović w 2015 roku wyraźnie opracowuje ten motyw. Zasadne jest zatem, postulowane przez Aleksandrę Ubertowską, tzw. czytanie retrospektywne (Ubertowska 2018: 21), czyli ponowna lektura tekstów powstałych przed laty, by uchwycić obecne w nich intuicje i usytuować je w obrębie nowych nurtów w humanistyce. 
Wskazując w tym miejscu jedynie na obecność pewnych wątków środowiskowych zwłaszcza w literaturze serbskiej, pragnę jednocześnie zwrócić uwagę na fakt, że funkcjonujący na terenie NDH (Niezależne Państwo Chorwackie) w czasie II wojny światowej kompleks obozowy Jasenovac położony był w bezpośrednim sąsiedztwie rzeki Savy, która w tej lokacji stanowi granicę pomiędzy Chorwacją i Bośnią. Intuicja podpowiada, że jej bliskość miała niebagatelne znaczenie dla życia więźniów internowanych w pobliskich obozach (przykładowo do wyczerpującej pracy przy budowie nasypu nad rzeką wysyłano więźniów znajdujących się na najniższym szczeblu obozowej hierarchii, czyli Romów, co przyspieszyło ich eksterminacje $\left.e^{12}\right)$. Wspomnienia obozowe $z$ Jasenovaca, wydawane w Chorwacji od lat dziewięćdziesiątych XX wieku, zdają się czekać na - nierzadko ponowne - sprofilowane środowiskowo odczytanie.

\section{| Bibliografia}

Acković Dragoljub (1994), Stradanje Roma u Jasenovcu, Abc Glas, Beograd.

Bajford Jovan (2011), Staro sajmište. Mesto sećanja, zaborava i sporenja, Beogradski centar za ljudska prava, Beograd.

Bogusławska Magdalena (2016), Zagłada Żydów w serbskim porządku pamięci, „Zagłada Żydów. Studia i materiały”, nr 9, s. 470-488, https://doi.org/10.32927/ZZSiM.431.

Browning Christopher R. (2012), Sajmiste as European Site of Holocaust Remembrance, "Filozofija i društvo", nr 4, s. 99-105.

Bukwalt Miłosz (2018), An der schönen blauen Donau... Obraz rzezi nowosadzkiej we współczesnej literaturze serbskiej, „Slavia Meridionalis”, nr 18, https://doi.org/10.11649/sm.1630.

Cseres Tibor (1980), Zimne dni, przeł. Tadeusz Olszański, PIW, Warszawa.

Czapliński Przemysław (2017), Poszerzanie pola Zagłady, „Teksty Drugie”, nr 2, s. 7-16, https://doi.org/10.18318/td.2017.2.1.

Dauksza Agnieszka, Koprowska Karolina, red. (2019), Świadek: jak się staje, czym jest?, IBL, Warszawa.

Giergiel Sabina (2019), Ciało, trup, śmierć w utworze Götz i Meyer Davida Albahariego, „Slavica Wratislaviensia: Tanatos”, nr 13/2, s. 553-564, https://doi.org/10.19195/0137-1150.168.47.

12 Pisze o tym Ilija Jakovljević $\mathrm{w}$ swych wspomnieniach $\mathrm{z}$ internowania w obozie Stara Gradiška (Jakovljević 1999: 54, 116) oraz serbski badacz Porajmosa, Dragoljub Acković (1994). 
Giergiel Sabina, Taczyńska Katarzyna (2019), Ślady (nie)pamięci o Porajmosie.

Kulturowa mapa romskiego Holokaustu w Serbii i Chorwacji, „Teksty Drugie”, nr 2, s. 317-336, https://doi.org/10.18318/td.2019.2.23.

Ivanji Ivan (2009), Aveti iz jednog malog grada, GNB Žarko Zrenjanin, Zrenjanin. Jakovljević Ilija (1999), Konclogor na Savi, Konzor, Zagreb.

Jarzyna Anita (2019), Post-koiné. Studia o nieantropocentrycznych językach (poetyckich), Wydawnictwo Uniwersytetu Łódzkiego, Łódź.

Kiš Danilo (1978), Klepsydra, przeł. Danuta Cirlić-Straszyńska, Wydawnictwo Literackie, Warszawa.

Kiš Danilo (1999), Życie, literatura, przeł. Danuta Cirlić-Straszyńska, Świat Literacki, Izabelin.

Kiš Danilo (2016), Psalm 44, przeł. Danuta Cirlić-Straszyńska, Książkowe klimaty, Wrocław.

Koljanin Milan (1992), Nemački logor na beogradskom Sajmištu 1941-1944, Institut za savremenu istoriju, Beograd.

Koš Erih (1961), Novosadski pokolj, Rad, Beograd.

Lujanović Nebojša (2015), Oblak boje kože, Fraktura, Zagreb.

Małczyński Jacek (2018), Krajobrazy Zagłady. Perspektywa historii środowiskowej, IBL, Warszawa.

Manošek Walter (2007), Holokaust u Srbiji. Vojna okupaciona politika i uništavanje Jevreja 1941-1942, przeł. Agnes Eremija i in., Službeni list SRJ, Draslar Partner, Beograd.

Mesta stradanja. Prva faza Holokausta u Srbiji i Hrvatskoj, http://cieh-chre.org/novi-sad/ [dostęp: 13.01.2021].

Niziołek Grzegorz (2013), Polski teatr Zagłady, Instytut Teatralny im. Z. Raszewskiego i Krytyka Polityczna, Warszawa.

Penevski Zoran (2005), Manje važni zločini, Okean, Beograd.

Piotrowiak-Junkiert Kinga (2015), O murze, którym była rzeka. Lament nad Dunajem Mihálya Kornisa, „Przestrzenie Teorii”, nr 24, s. 109-123, https://doi.org/10.14746/pt.2015.24.6.

Pisma Hilde Dajč, https://tinyurl.com/53yp3vzk [dostęp: 17.01.2021].

Rotbart Vladislav (2013), Čija je novosadska racija. Prilog istoriji Jevreja u Bačkoj, $\mathrm{w}$ : Jevrejstvo, antisemitizam i holokaust. Zbornik radova, red. Đorđe N. Lopičić, Forma 1, Ljubljana, s. 282-308.

Sendyka Roma (2018), Od obserwatorów do gapiów. Kategoria bystanders i analiza wizualna, „Teksty Drugie”, nr 3, s. 117-130, https://doi.org/10.18318/td.2008.3.7.

Sendyka Roma (2019), Śledztwo i łowy. Nie-miejsca pamięci i krajobraz cynegetyczny, w: Poetyki ekocydu. Historia, natura, konflikt, red. Aleksandra Ubertowska, Dobrosława Korczyńska-Partyka, Ewa Kuliś, IBL, Warszawa, s. $87-110$. 
Todorić Gordana, Sameravanje čoveka, (Posłowie do drugiego wydania powieści Eriha Koša Novosadski pokolj [Jevrejska opština, Mala knjiga, Novi Sad 2014] dostępne w formacie word na stronie academia.edu), https://tiny.pl/rppif [dostęp: 12.02.2021].

Spomenik Žrtvama Racije, https://tinyurl.com/442bynce [dostęp: 20.06.2021]. Ubertowska Aleksandra (2018), „Mówić w imieniu biotycznej wspólnoty”. Anatomie i teorie tekstu środowiskowego/ekologicznego, „Teksty Drugie”, $\mathrm{nr} 2$, s. 17-40, https://doi.org/10.18318/td.2018.2.2.

Vojinović Živana (2015), Avramova deca. Pomenik šabačkih i podrinskih Jevreja, OrionArt, Beograd.

\section{| Abstrakt}

\section{Sabina Giergiel}

„Rzeka to nie ziemia, przyjmie wszystko”. Uwag kilka o przyrodniczych uwarunkowaniach Zagłady w Serbii

Celem tekstu jest pokazanie, że w Serbii (podobnie jak w innych krajach) Holokaust nie wydarzył się w środowiskowej próżni. Rozważania koncentrują się wokół obrazów literackich, w których ujawnia się relacja pomiędzy przyrodą a lokalizowaniem i funkcjonowaniem obozów oraz losem więźniów. Szczególne miejsce poświęcone zostaje rzece, która w literaturze serbskiej staje się ważnym toposem holokaustowym. Rzeka symbolizuje w niej najczęściej masowy grób, mur czy zasłonę, jak również (w warunkach zimowych) scenę. Wówczas najczęściej występuje w roli mimowolnego sprzymierzeńca nazistów. Jednak obok takiego rozumienia rzeki, w którym akcentowany jest bierny charakter przyrody, w literaturze serbskiej (i chorwackiej) odnaleźć można również obrazy, w których przedstawiona jest ona jako podmiot sprawczy. Występując w tej roli, przechodzi z drugiego planu (zwykle zarezerwowanego dla warunków przyrodniczych) na plan pierwszy i stawia opór tym, którzy zadają gwałt zarówno ofiarom, jak i przyrodzie.

Słowa kluczowe: Serbia, Holokaust, rzeka, środowisko, oddalenie 


\section{| Abstract}

Sabina Giergiel

\section{"A River is not the Same as Soil, It will Accept Everything": A Few Notes on the Environmental Conditions of the Holocaust in Serbia}

The article aims at demonstrating that in Serbia (as in other countries) the Holocaust did not occur in an environmental vacuum. The considerations focus on the literary representations of the triple relation between nature, the camps' location and functioning, as well as the fates of the prisoners. The river appears to be of the greatest importance, as it becomes a very prominent Holocaust motif in the Serbian literature. In most cases, a river symbolizes a mass grave, a wall, a curtain, or - in winter conditions - a stage. Hence, it most frequently becomes the Nazis' involuntary ally. However, apart from this reading of a river - i.e. as a passive component of nature - there are also its representations in the Serbian (and Croatian) literature in which its agential qualities are emphasised. Acting as that, a river moves from the background (usually reserved for environmental conditions) to the foreground, and thus resists those who violate both human victims and nature.

Keywords: Serbia, the Holocaust, river, environment, space distance

\section{| Biogram}

Sabina Giergiel - dr hab., literaturoznawczyni, pracuje w Instytucie Filologii Słowiańskiej UJ. Zainteresowania badawcze: reprezentacje przeszłości we współczesnej kulturze Serbii i Chorwacji. Kierowniczka i wykonawczyni projektu Pamięć o powojennych doświadczeniach Banackich Niemców $w$ transgeneracyjnym przekazie ustnym, finansowanego przez NCN (nr 2019/o3/X/HS3/oo128). Najnowsze publikacje: Additional Testimony. Photographs in the Prose of Daša Drndić, "Fluminensia" 2020, nr 1, s. 39-52, Ślady (nie)pamięci o Porajmosie. Kulturowa mapa romskiego holokaustu w Serbii i Chorwacji, “Teksty Drugie” 2019, ss. 317-336 (współautorstwo: Katarzyna Taczyńska).

E-mail: sabina.giergiel@uj.edu.pl

ORCID: 0000-0002-5706-5679 